\title{
Mahasiswi Sebagai Ibu Muda (Studi Antropologi Sosial Di Kota Lhokseumawe)
}

\author{
Malahayati \\ Prodi Antropologi FISIP Universitas Malikussaleh
}

\begin{abstract}
Abstrak
Analisis ini mengkaji tentang Mahasiswi Sebagai lbu Muda Antropologi Sosial di Kota Lhokseumawe. Penelitian ini menggunakan pendekatan kualitatif yang bersifat deskriptif dengan teknik observasi, wawancara mendalam, analisis data yang diperkuat dengan studi dokumen, studi literatur dan studi kepustakaan. Dalam membedah penelitian ini penulis menggunakan studi antropologi sosial. Hasil penelitian menunjukkan bahwa di era modern seperti saat ini munculnya fenomena ibu muda, khususunya dari kalangan mahasiswi adalah sesuatu yang baru dan terlihat seperti berseberangan dengan tradisi masa lalu. Kehidupan ibu muda dalam mengelola keluarganya sangat berbeda dengan ibu-ibu tempo dulu. Kebanyakan ibu muda saat ini cenderung konsumerisme dan mengarah ke berbagai hal-hal yang instan. Ibu muda yang seperti ini sebahagiannya masih berstatus mahasiswi. Mahasiswi sebagai ibu muda banyak ditemukan di Kota Lhokseumawe. Maka dari itu, penelitian ini sangat relevan dilakukan demi melihat dan mencari tahu bagaimana keseharian ibu-ibu muda dalam kacamata antropologi sosial. Menjadi ibu muda dengan masih mengemban status mahasiswi tentu sebuah kerja keras dan tidak mudah. Berbagai hal rumah tangga dan perkuliahan bisa bentrok kapan saja tanpa bisa diterka. Mahasiswi sebagai ibu muda mendapatakan masalah jika saja tidak pintar membagi waktu mengurusi keluarga dan kuliahnya. Mengurusi keduanya sungguh sangat tidak mudah. Lantas, kenapa mahasiswi tetap memilih menjadi ibu muda walau masih kuliah padahal mereka cukup sadar bahwa hal tersebut adalah pilihan yang sangat besar risikonya? Hal inilah yang akan penulis urai lebih dalam dalam penelitian ini, sehingga masyarakat luas mengetahui bagaimana berat dan sulitnya kehidupan mahasiswi yang menjadi ibu muda. Ada berbagai faktor yang melatarbelakangi sehingga mahasiswi memilihj menikah dan menjadi ibu muda walau masish berstatus mahasiswi.
\end{abstract}

Kata kunci: Ibu Muda, Era Modern, Antropologi Sosial, Mahasiswi . 


\section{Pendahuluan}

Keluarga merupakan unit kesatuan sosial terkecil yang mempunyai peranan yang sangat penting dalam membina anggota-anggotanya. Setiap anggota dari suatu keluarga dituntut untuk mampu dan terampil dalam mananamkan peranan sesuai dengan kedudukannya. Pada dasarnya keluarga dapat dibedakan menjadi dua yaitu keluarga inti (nulear family) dan keluarga luas (etended family). Keluarga inti adalah keluarga yang terdiri dari ayah, ibu, dan anak-anak yang belum menikah. Keluarga ini dapat dikategorikan lagi menjadi keluarga inti yang tidak lengkap yang terdiri atas ayah dan anak-anaknya atau ibu dan anak-anaknya, serta pasangan yang baru menikah atau tidak punya anak (Ritonga et al, 1996:64).Keluarga merupakan lingkungan pertama kali berpengaruh terhadap prilaku anak. setiap anggota keluarga mempunyai peranan yang sangat penting terutama peran ayah, dan ibu ( Haryoko, 1997:39).

Keluarga adalah perkumpulan dua atau lebih individu yang diikat oleh hubungan darah, perkawinan atau adopsi dan tiap-tiap anggota keluarga selalu berinteraksi satu sama lain. Keluarga adalah satu persekutuan hidup yang dijalanin dengan penuh kasih sayang antara pasangan dua jenis manusia yang dikukuhkan dengan pernikahan, yang bermaksud untuk saling menyempurnakan diri (Mubarak, 2009:89).Keluarga mempunyai beberapa fungsi yaitu agama, sosial budaya, cinta kasih, melindungi, reproduksi, sosialisai dan pendidikan, ekonomi, dan pembinaan lingkungan. Beberapa fungsi keluarga ini menjadi prasyarat, acuan dan pola hidup setiap keluarga dalam rangka terwujudnya keluarga sejahtera dan berkualitas (BKKBN, 2013).

Pola asuh merupakan interaksi anak dan orang tua yang mendidik, membimbing, dan mendisiplinkan serta melindungi anak untuk mencapai kedewasaan sesuai dengan norma-norma yang ada dalam masyarakat. Interaksi anak dengan orang dewasa dan sesamanya di lingkungan keluarga dapat menstimulasi perkembangan anak tersebut. Contohnya, interkasi anak dengan ibu yang merupakan interaksi yang paling efektif untuk menjalin kedekatan dengan anak, serta berpengaruh kepada perkembangan anak. Interakasi ini dapat mempengaruhi perkembangan persepsi, membimbing serta dapat mengendalikan perilaku anak-anak tersebut. Selain itu juga membantu mendapatkan pengetahuan dan keterampilan diri mereka di lingkungannya (Edwards, 2006:12). Pengasuhan merupakan kebutuhan dasar anak untuk tumbuhdan berkembang secara optimal. Pada masa bayi, anak masih benar-benar tergantung pada perawatan dan pengasuhan oleh ibunya. Pengasuhan kesehatan dan makanan pada tahun pertama kehidupan sangatlah penting 
untuk perkembangan anak. Pola pengasuhan bayi tidak sama bentuknya di setiap keluarga. Hal ini dipengaruhi oleh faktor-faktor yang mendukungnya antara lain latar belakang pendidikan ibu, pekerjaan ibu, status gizi ibu, jumlah anak dalam keluarga, dan sebagainya.

Peran orang tua dalam proses pengasuhan anak juga berfungsi sebagai sosialisasi yang merupakan proses membina sosialisasi pada anak, membentuk norma-norma dan tingkah laku sesuai dengan tingkat perkembangan masing-masing dan meneruskan nilai-nilai budaya. Fungsi sosialisasi ini merupakan fungsi yang mengembangkan proses interaksi dalam keluarga yang dimulai sejak lahir dan keluarga merupakan tempat individu untuk belajar bersosialisasi (Mubarak, 2009:90).

Pengaruh keluarga besar (extended family) memberi warna pada pengasuhan anak, di mana anak melalui proses sosialisasi mengenal aneka ragam orang yang mempunyai caranya sendiri sesuai dengan posisnya di dalam keluarga itu (Alfian, 1977). Pendidikan dalam keluarga tidak hanya tentang bagaimana meningkatkan fungsi kognitif atau mencerdaskan anak saja, tetapi juga membentuk karakter anak perlu diajari untuk membedakan mana yang salah dan benar, mana yang hak dan mana yang bathil, serta bagaimana agar tetap hidup benar di lingkungan yang salah.

Saat ini, fenomena munculnya ibu-ibu muda di Kota Lhokseumawe sudah banyak ditemukan. Mereka adalah ibu-ibu muda yang berbeda pendapat serta cara mengasuh anak dengan orang tua kita di masa dulu. Kebanyakan ibu muda yang berada di Kota Lhokseumawe saat ini masih berusia produktif dengan status mahasiswi, sehingga pengetahuannya tentang pola mengasuh anak sangat minim serta tidak sebanyak pengetahuan yang dimiliki oleh ibu-ibu di masa lalu. Tren ibu muda di Kota Lhokseumawe sekarang mulai menunjukkan beberapa persoalan. Ibu-ibu muda tersebut selain tidak memiliki pengalaman yang cukup untuk merawat bayi juga enggan memberikan ASI kepada anaknya.

Bentuk tubuh yang indah, ibu-ibu muda tersebut akan memberikan anaknya susu formula sebagai pengganti ASI. Karena orang tua sekarang sangat berbeda budaya dengan orang tua dulu. Belum lagi saat ini perkembangan teknologi semakin memberikan kemudahan bagi ibu dalam mengasuh anak.Tidak hanya itu, karena kesibukan dan aktifitas seorang ibu yang masih berstatus mahasiswi membuat pola asuh anak agak sedikit berbeda, misalnya anak yang dititipkan kepada kerabat, tempat penitipan anak, bahkan juga dititipkan ketetangga. 
Juliana (2008), pola pemilihan makanan yang di praktekkan para ibu guna menapai pertumbuhan yang ideal pada balita, kemudian memaparkan hasil pengetahuan ibu tentang merawat balita. Penelitian ini menggunakan penelitian Kualitatif dengan menggunakan metode wawancara dan pengamatan langsung di lapangan.Yusmanidar (2006), proses perawatan bayi di Gampong Blang Crum kemudian memaparkan hasil merawat bayi. penelitian ini menggunakan metode wawanara dan pengamatan langsung di lapangan.

Perkawinan dalam antropologi, didefinisikan sebagai salah satu tahapan dalam lifecycle manusia. Secara umum masyarakat sering kali mengartikan bahwa perkawinan adalah hal yang harus dilalui oleh setiap individu yang normal. Dalam perjalanannya perkawinan kemudian menjadi hal yang tidak hanya melibatkan orang atau individu yang berbeda kelamin yang hendak membangun keluarga, tetapi juga masyarakat yang melingkup kehidupan mereka. Di titik persoalan budaya, campur tangan agama, dan intervensi negara, menjadi seperangkat regulasi yang pada akhirnya ikut mendefinisikan perkawinan. Di Indonesia salah satu masalah yang berkenan dengan perkawinan adalah perkawinan dini, sementara studistudi mengenai hal ini belum banyak dilakukan, padahal masalah ini juga bersentuhan dengan nilai budaya dalam masyarakat, sehingga tidak akan melakukan hal-hal yang membawa aib bagi keluarga seperti hamil diluar nikah, karena perbuatan ini akan membuat siri (Thontowi, 2007:88).

Orang tua muda dalam menyiapkan anak untuk masa depan dapat disimpulkan dalam pendidikan anak usia dini sangat berpengaruh dalam meletakkan fondasi kecerdasan anak untuk bekal belajar lebih lanjut di hari kedepan, karena perlu diingat bahwa pendidikan anak adalah tanggung jawab orang tua, keluarga, tidak ada alasan karena tuntutan orang tua melalaikan tanggung jawabnya, atau sama sekali tidak menyisakan waktu untuk mendidik anak di rumah karena itu besarnya peranan seorang ibu dalam meletakkan dasar-dasar perkembangan kecerdasan anak. Demikian pula dengan ayah dan peran masyarakat dibutuhkan dalam penciptaan suasana yang menunjang pendidikan anak usia dini (Seto, 2004:40).

Pernikahan yang saat ini sedang banyak berkembang di kalangan mahasiswa juga diharapkan mampu membawa pengaruh positif misalnya dalam hal prestasi akademik dan kemamampuan bersosialisasi dengan orang lain di sekitar. Sehingga pernikahan usia dini mampu mendukung mahasiswa dalam meningkatkan kualitas diri dan daya saing di era modernisasi, baik dari segi akademik maupun sosial. Setiap keputusan yang diambil menimbulkan dampak positif dan negatif yang ditemukan misalnya soal membagi waktu untuk menyelesaikan kewajiban kuliah 
dengan kewajiban di rumah sebagai seorang istri.sehingga sering ada salah satu kewajiban yang terpaksa harus di tinggalkan, seperti tugastugas di kampus dan kewajiban sehari-hari dirumah sebagai seorang istri untuk dampak positifnya misalnya kebahagian, bahagia setelah menikah karena kehadiran pasangan hidup dan anak. Selain itu merasa lebih dewasa dan hidup lebih tertata setelah menikah (Ansori, 2015:52).

\section{Metodelogi Penelitian}

Metode penelitian adalah prosedur yang dilakukan oleh seseorang untuk mendapatkan data ataupun informasi untuk memperoleh jawaban atas permasalahan penelitian. Dalam melaksanakan penelitian ini peneliti menggunakan metode penelitian kualitatif deskriptif dan pendekatan budaya. Metode deskriptif adalah suatu metode dalam meneliti status sekelompok manusia, suatu objek, suatu kondisi, suatu kondisi, suatu sistem pemikiran ataupun suatu peristiwa pada masa sekarang. Tujuan dari pendekatan dengan metode kualitatif deskribtif ini adalah untuk membuat deskripsi, gambaran, pemaknaan secara sistematis, faktual aktual, akurat mengenai fakta-fakta sifat yang berhubungan antara fenomena yang diselidiki.Dalam penelitian ini penulis mengunakan metode studi etnografi sosial yaitu mengenai perhatian tentang ciri-ciri dan sifatsifat masyarakat bagaimana manusia berhubungan satu sama lain, dan bagaimana masyarakat berubah sepanjang waktu dan mengapa masyarakat berubah sepanjang waktu (Moleong, 2000:46). Data yang diperoleh kemudian dianalisis secara kualitatif dengan menggunakan model analisis interaktif. Analisa merupakan bagian yang amat penting dalam suatu penelitian, karena dengan analisis data yang diperoleh melalui telaah, observasi, wawancara dan dokumentasi akan diklasifikasi sesuai dengan jenis dan sifatnya kemudian akan dianalisis dengan teknik dan teori yang mendukung selanjutnya diberikan arti atau makna yang akan digunakan dalam penelitian yang dilakukan (Burhan Bungin, 2001:59).

\section{Hasil dan Pembahasan \\ Gambaran umum Lokasi}

Kota Lhokseumawe merupakan pemekaran dari Kabupaten Aceh Utara dan terletak di pesisir timur Pulau Sumatera. Posisi Kota Lhokseumawe berada di antara Kota Banda Aceh dan Medan menjadikan kota ini sangat strategis sebagai jalur distribusi dan perdagangan di Aceh. Pada awal terbentuknya pada tahun 2001, Kota Lhokseumawe terdiri atas tiga kecamatan dan hingga saat ini Kota Lhokseumawe telah terdiri atas empat kecamatan. 
Masyarakat Kota Lhokseumawe pada umumnya menggunakan Bahasa Aceh dalam berkomunikasi, tetapi ada juga yang menggunakan Bahasa Indonesia sebagai bahasa nasional. Bahasa Indonesia di kalangan masyarakat Kota Lhokseumawe biasanya digunakan di lingkungan formal seperti di sekolah dan kantor-kantor pemerintahan. Bahasa Indonesia di lingkungan formal seperti sekolah, perkantoran dan institusi pemerintahan atau swasta lainnya digunakan sebagai sarana berekspresi dan berkomunikasi antar individu di lingkungan formal tersebut.

Sedangkan Bahasa Aceh yang merupakan bahasa lokal biasa digunakan oleh masyarakat Kota Lhokseumawe di lingkungan sosial yang bukan merupakan lingkungan formal seperti di rumah, di pasar tradisional, lembaga masyarakat seperti meunasah, di perkampungan dan sebagainya. Bahasa Aceh sebagai bahasa lokal tetap digunakan demi melestarikan dan menjaga keutuhan nilai-nilai lokal masyarakat Kota Lhokseumawe. Kolaborasi Bahasa Indonesia dan Bahasa Aceh menunjukkan kekayaan budaya bangsa Indonesia, khususnya dalam bidang linguistik dan adat masyarakat lokal suatu daerah.

Kondisi sosial budaya masyarakat Kota Lhokseumawe sebagian besar terlihat dipengaruhi oleh kondisi budaya perkotaan. Namun masyarakat Kota Lhokseumawe masih menjalin hubungan kekerabatan dan menjunjung tinggi nilai-nilai solidaritas masyarakat yang baik. Seperti masih membudayakan gotong royong, saling membantu serta saling mengujungi kerabat-kerabat yang terkena musibah. Budaya dan kehidupan sosial masyarakat masih sangat terasa di Kota Lhokseumawe dengan adanya rasa saling tolong menolong.

Masyarakat Kota Lhokseumawe kebanyakan banyak menggunakan bahasa Indonesia dalam kehidupan sehari-hari umumnya pada saat keluar rumah untuk berkomunikasi dengan orang lain. Namun juga ada yang menggunakan bahasa daerah (Aceh) dalam berkomunikasi sesama teman akrab atau keluarganya. Tetapi juga menggunakan Bahasa Indonesia itu sebagai bahasa pengantar yang biasa digunakan jika berhadapan dengan pendatang dari luar daerah yang kurang memahami Bahasa Aceh. Oleh karena itu bahasa dapat dijadikan pemersatu identitas suku bangsa.

Pola hubungan sosial antar penduduk juga masih sangat kental di Kota Lhokseumawe. Ini terlihat melalui jalinan kekerabatan yang berdasarkan pengamatan penulis sangat menunjukkan tali persaudaraan. Walaupun ada terjadi suatu konflik antar penduduk seperti terjadinya kesalahpahaman maka dapat diselesaikan secara kekeluargaan, musyawarah dan mufakat. Keadaan penduduk di daerah Kota Lhokseumawe sebagian besar telah menuju kearah kemajuan, teknologi, 
bahasa, budaya. Masyarakat Kota Lhokseumawe sebagian besar masih mengandalkan hidup dari profesinya yaitu sebagai nelayan atau petani. Selain itu, masyarakat Kota Lhokseumawe juga banyak yang mempunyai pekerjaan tetap seperti Pengawai Negeri Sipil (PNS) dan wiraswasta.

\section{Mahasiswi sebagai Ibu Muda di Kota Lhokseumawe}

Mahasiswa sebagai ibu muda di Kota Lhokseumawe adalah sebuah fenomena sosial yang sering ditemui saat ini. Hal ini muncul sebagai salah satu gejala perilaku sosial di tengah masyarakat Kota Lhokseumawe. Munculnya trend mahasiswa sebagai ibu muda di Kota Lhokseumawe pada dasarnya tidak selalu membawa hal-hal negatif, ada hal positif yang datang bersama dengan fenomena tersebut. Faktor-faktor yang melatarbelakangi maraknya trend mahasiswa sebagai ibu muda sangat beragam. Hal ini penulis temukan saat penelitian di lapangan.

Adapun di antara faktor yang melatarbelakangi munculnya trend mahasiswa sebagai ibu muda di Kota Lhokseumawe antara lain: faktor ekonomi, faktor pergaulan remaja, dan faktor lingkungan. Di antara faktor tersebut, faktor ekonomi mendominasi munculnya trend mahasiswa sebagai ibu muda di Kota Lhokseumawe. Beberapa informan yang penulis wawancarai mengatakan bahwa pernikahan muda adalah salah satu jalan untuk memulai kehidupan baru dan meringankan kebutuhan ekonomi keluarga.

Demi mendapatkan dapat yang valid, penulis melakukan wawancara dengan beberapa informan terkait trend mahasiswa sebagai ibu muda di Kota Lhokseumawe. Berikut wawancara penulis dengan Atika Suri (22 tahun), mahasiswi semester 4 jurusan PGTK, Universitas Almuslim, Cunda, Lhokseumawe. Salah satu mahasiswi yang sudah menjadi ibu muda di Kota Lhokseumawe.

"Menikah di usia muda sebenarnya bukan hal yang baru di Lhokseumawe. Sudah banyak yang menikah muda dengan berbagai alasan. Saya menikah pada Oktober 2015. Usia saya saat itu 20 tahun, suami 22 tahun. Menurut saya, menikah di usia dini adalah hal baik daripada pacaran lama-lama. Teman-teman juga ada yang lebih dulu menikah" (Wawancara, 10 Januari 2016).

Penulis juga mewawancarai Siti Rahma (24 tahun), mahasiswi Akademi Kebidanan Pemerintah Kabupaten Aceh Utara. Berikut wawancara dengannya terkait fenomena trend mahasiswa sebagai ibu muda di Kota Lhokseumawe: 
"Menikah dan menjadi ibu muda saat ini adalah hal yang sudah biasa. Ini bisa dilihat dari banyaknya pemuda yang menokah di usia dini. Namun, yang tetap kuliah setelah menikah masih sedikit. Ini diakibatkan beberapa faktor, salah satunya faktor ekonomi dan faktor internal lainnya seperti tidak mendapat dukungan suami dan keluarga. Alhamdulillah saya masih bisa melanjutkan kuliah meskipun sudah menikah dan memiliki anak. Ada beberapa teman yang tidak melanjutkan kuliah setelah menikah karena faktor-faktor yang saya sebutkan barusan" (Wawancara, 8 Januari 2016).

Terkait fenomena mahasiswa sebagai ibu muda di Kota Lhokseumawe, penulis juga mewawancarai Asmawati (45 tahun), salah satu bidan yang bekerja di salah satu rumah sakit di Kota Lhokseumawe. berikut kutipan wawancaranya:

"Menikah dini sebenarnya adalah hal positif. Artinya, dengan menikah dini para remaja yang menikah tersebut paling tidak sudah menjaga nama baik dengan tidak berpacaran sampai melakukan hal-hal yang tidak diinginkan. Namun di sisi lain, menikah dini juga menimbulkan beberapa hal yang cenderung negatif dan merugikan yang menikah, terutama dalam hal karir dan pendidikan. Banyak yang menikah dini kemudian tidak bisa melanjutkan studi maupun kerja. Ini karena faktor kesibukan mengurus keluarga dan ekonomi juga. Ini disayangkan" (Wawancara, 10 Januari 2016).

Dari wawancara di atas bisa kita simpulkan bahwa trend mahasiswa sebagai orang tua muda di Kota Lhokseumawe sudah menjadi hal biasa dan tidak dianggap tabu. Ini karena pernikahan usia dini yang melibatkan remaja, khususnya mahasiswa sudah banyak ditemukan. Namun, trend mahasiswa sebagai ibu muda masih menimbulkan berbagai penilaian dari beberapa kalangan. Trend mahasiswa sebagai ibu muda menandakan bahwa masyarakat Kota Lhokseumawe sudah menerima salah satu gejala sosial di tengah-tengah mereka dengan baik dan terbuka.

\section{Profil Mahasiswi sebagai Ibu Muda di Kota Lhokseumawe}

Berikut adalah profil mahasiswa sebagai ibu muda di Kota Lhokseumawe yang menjadi informan dalam penelitian ini.

\section{Atika Suri}

Atika Suri adalah seorang ibu muda yang masih kuliah di Universitas Almuslim, Cunda Lhokseumawe pada Jurusan Pendidikan Guru TK (PGTK). Saat ini Atika Suri berusia 22 tahun. Atika Suri sendiri adalah seorang perempuan yang dilahirkan pada tanggal 12 Mei 1995 di Pusong, Kota Lhokseumawe. Lahir di keluarga sederhana dengan perekonomian 
pas-pasan membuat masa kecil Atika Suri jauh dari kata mewah. Ayahnya bernama Bapak Tgk M. Sufi. Beliau adalah seorang nelayan di Pusong. Sedangkan ibunya bernama ibu Halimah. beliau adalah seorang ibu ibu rumah tangga. Penghasilan orang tuanya yang tergolong tidak menentu setiap bulannya membuat Atika Suri sudah terbiasa merasakan keterbatasan dalam bidang ekonomi, sehingga hal inilah yang kemudian menjadi salah satu faktor dia menikah dini.

Pernikahan dini Atika Suri sedikit banyak ditentukan oleh keadaan ekonomi keluarga yang tergolong sederhana. Lahir di dalam keluarga yang sederhana dengan ekonomi di bawah rata-rata memang menjadi alasan tersendiri bagi Atika Suri menikah muda. Dalam pemikirannya, menikah dini dan membangun keluarga bersama suaminya adalah salah satu jalan terbaik untuk memperbaiki kehidupannya dan juga keluarganya, terutama di bidang perekonomian. Atika berpendapat jika dia menikah dan membangun rumah sendiri bersama sang suami secara tidak langsung dia sudah membantu meringankan beban perekonomian keluarganya.

\section{Siti Rahma}

Siti Rahma adalah seorang ibu muda yang masih kuliah di Akademi Kebidanan Pemerintah Aceh Utara. Saat ini Siti Rahma berusia 24 tahun. Siti Rahma sendiri adalah seorang perempuan yang dilahirkan pada tanggal 3 Juli 1993 di Gampong Meunasah Mesjid, Kota Lhokseumawe.

Siti Rahma memiliki keluarga yang tergolong memadai dengan perekonomian stabil. Ayahnya adalah Bapak Hasbi M. Nur, dia adalah seorang pegawai pemerintahan di Kota Lhokseumawe, sedangkan ibunya, Ibu Nurjani, adalah ibu rumah tangga. Penghasilan orang tuanya yang tergolong memadai dan teratur setiap bulannya membuat Siti Rahma sudah terbiasa merasakan kecukupan di bidang ekonomi. Siti Rahma menikah dini bisa dikatakan atas kemauan sendiri. Siti Rahma juga menikah dengan orang yang sudah lama berteman dekat dengannya. Mereka sudah memiliki sebuah hubungan sebelum kuliah. Untuk menjaga nama baik keluarga dan kehormatan, maka Siti Rahma memutuskan menikah dini dengan pasangan kekasihnya.

\section{Ira Ramadhani}

Ira Ramadhani adalah seorang ibu muda yang masih kuliah di Universitas Malikussaleh, Jurusan Kesekretariatan (PDPK). Saat ini Ira Ramadhani berusia 22 tahun. Ira Ramadhani sendiri adalah seorang perempuan yang dilahirkan pada tanggal 22 Mei 1995 di Uteun Bayi, Kota Lhokseumawe. Lahir di keluarga sederhana dengan perekonomian menengah ke bawah membuat masa kecil Ira Ramadhani dengan serba pas-pasan. Ayahnya bernama Bapak Hamidi adalah seorang buruh bangunan. Sedangkan ibunya bernama lbu Sabariah adalah ibu rumah tangga. Penghasilan orang 
tuanya, khususnya ayahnya sebagai seorang tukang bangunan tidak menentu setiap bulannya, hal ini membuat Ira Ramadhani sudah terbiasa merasakan menjalani kehidupan dengan keterbatasan ekonomi.

Nova Syahwani

Nova Syahwani adalah seorang ibu muda yang masih kuliah di Akademi Kebidanan Pemda Aceh Utara. Saat ini Nova Syahwani berusia 25 tahun. Nova Syahwani sendiri adalah seorang perempuan yang dilahirkan pada tanggal 12 Oktober 1992 di Meunasah Mesjid, Kota Lhokseumawe. Lahir di keluarga sederhana dengan perekonomian berkecukupan membuat masa kecil Nova Syahwani sama seperti teman-teman yang seusia dengannya. Jauh dari kata mewah, namun bahagia. Ayahnya bernama Bapak Fakhruddin, beliau adalah seorang pedagang buah. Sedangkan ibunya bernama Ibu Nuraini, beliau adalah ibu rumah tangga.

\section{Faktor-Faktor Pendorong Mahasiswi sebagai lbu Muda}

Faktor Kemauan Diri Sendiri dan Orang Tua

Berdasarkan ceritanya pada saat wawancara, Ira Ramadhani mengatakan bahwa faktor yang menyebabkan dirinya menikah dini salah satunya adalah faktor kemauan diri sendiri. Namun, kemauan orang tua agar dirinya segera menikah dengan calon yang telah mereka tentukan adalah faktor lain yang menyebakan Ira Ramadani.

Berikut adalah kutipan wawancara dengan Ira Ramadhani terkait faktor dirinya menikah bebarapa tahun lalu:

"Banyak yang bilang kalau pernikahan muda selalu disebabkan oleh hal-hal negatif sebelumnya, salah satunya seperti faktor ekonomi keluarga yang kurang mampu. Padahal tidak semua orang menikah muda karena faktor ekonomi. Saya sendiri menikah dini bukan karena faktor itu. Kami menikah karena keinginan satu sama lain dan didukung oleh keluarga. Memang banyak yang menikah dini salah satu penyebabnya adalah faktor ekonomi, tapi tidak semuanya" (Wawancara, 8 Januari 2016).

Masih berdasarkan hasil wawancara dengan informan lain dalam penelitian ini, Siti Rahma, salah satu ibu muda yang masih kuliah di Akademi Kebidanan Pemerintah Abupaten Aceh Utara juga mengatakan dirinya menikah dini juga atas dasar kemauan sendiri. Berdasarkan ceritanya, pada saat menikah Siti Rahma berusia 20 tahun, sedangkan suaminya berusia 24 tahun. Siti Rahma menikah dengan orang yang sudah lama berteman dekat dengannya. Mereka sudah memiliki sebuah hubungan sebelum kuliah yang akhirnya diresmikan oleh sebuah ikatan suci bernama pernikahan. 
Berikut adalah wawancara dengan Siti Rahma terkait faktor diri sendiri dan orang tua sebagai pendorong pernikahan dini:

"Menikah di usia dini harus dipikirkan secara matang dan yakin. Harus mendapat restu dari keluarga, terutama orang tua. Faktor orang tua sangat memengaruhi seseorang memutuskan untuk menikah pada waktu tertentu. Terkait menikah dini, ada sebagian orang tua tidak memberikan izin semudah itu kepada sang anak, namun jika sang anak sudah memiliki pasangan sendiri dan mau serius, orang tua pasti memahami dan merestui" (Wawancara, 8 Januari 2016).

\section{Faktor Ekonomi}

Berdasarkan penuturannya pada saat wawancara, Atika Suri mengatakan bahwasanya faktor yang menyebabkan dirinya menikah dini sedikit banyak ditentukan oleh keadaan ekonomi keluarga yang tergolong sederhana. Keluarganya yang sederhana dengan ekonomi di bawah rata-rata memang menjadi alasan tersendiri bagi Atika Suri memutuskan untuk menikah muda. Dalam pemikirannya, menikah dini dan membangun keluarga bersama suaminya adalah salah satu jalan terbaik untuk memperbaiki kehidupannya dan juga keluarganya, terutama di bidang perekonomian. Atika berpendapat jika dia menikah dan membangun rumah sendiri bersama sang suami sefcara tidak langsung dia sudah membantu meringankan beban perekonomian keluarganya.Berikut adalah wawancara dengan Atika Suri:

"Saya dulu menikah karena berpikir jika menikah dan mempunyai rumah sendiri dengan suami akan meringankan beban orang tua. Tinggal bersama orang tua dengan kondisi perekonomian keluarga pas-pasan sangat memengaruhi saya untuk segera menikah dan memiliki rumah sendiri meskipun sederhana" (Wawancara, 10 Januari 2016).

\section{Faktor Lingkungan}

Masih terkait faktor-faktor yang mendorong remaja di Kota Lhokseumawe, khususnya mahasiswa menikah dini dan menjadi orang tua muda, selain disebabkan oleh faktor kemauan sendiri serta orang tua dan faktor ekonomi, ternayata ada faktor lain yang termasuk kedalamnya, yaitu faktor lingkungan. Hal ini setidaknya tergambar dari pengalaman Nova Syahwani. Nova adalah salah satu informan dalam penelitian ini. Berdasarkan cerita dan pengalamannya, ibu muda di Kota Lhokseumawe yang masih aktif kuliah pada Akademik Kebidanan Pemda Aceh Utara ini mengatakan bahwa dirinya menikah dini karena faktor lingkungan. Pada saat menikah usianya adalah 23 tahun. Adapun usia suaminya adalah 30 tahun.

Menurut Nova, lingkungan pergaulan remaja di Kota Lhokseumawe sudah sangat patut dikhawatirkan. Ini berdasarkan banyaknya remaja- 
remaja yang terpaksa menikah dini karena kondisi lingkungan. Sehingga menurut Nova, menikah dini, apalagi dengan orang yang sudah dikenalnya adalah jalan terbaik untuk menjaga nama baik keluarga dan dirinya sendiri. Faktor ini adalah salah satu faktor yang identik dengan pergaulan. Berbicara faktor lingkungan adalah berbicara tentang tempat hidup, bermain dan beraktifitas sehari-hari dalam menjalani kehidupan. Dalam dunia moderen yang serba bebas dan maju, faktor lingkungan sangat memiliki andil dalam berbagai lini kehidupan seseorang individu, baik dalam pembentukan karakter berpikir, bertindak dan beragama.

Berikut adalah wawancara dengan Nova Syahwani (25 tahun), mahasiswi Akademi Kebidanan Pemda Aceh Utara, salah satu orang tua muda di Kota Lhokseumawe yang menikah dini karena faktor lingkungan:

"Saya menikah beberapa waktu lalu bisa disebut didorong oleh faktor lingkungan sekitar. Pergaulan dan lingkungan sangat mempengaruhi perilaku seseorang dalam bersikap dan beraktifitas sehari-hari. Faktor lingkungan juga menjadi cerminan seseorang dalam bertindak. Terkait trend menikah dini dan mahasiswa sebagai orang tua muda, saya pikir memang dipengaruhi oleh faktor lingkungan. Ada juga teman saya di kampus yang menikah karena takut dibilang gak laku, karena di daerah tempat tinggalnya rata-rata perempuan seumur dengannya sudah menikah" (Wawancara, 11 Januari 2016).

Nova Syahwani melanjutkan komentarnya terkait faktor lingkungan sebagai pendorong munculnyya keadaan sosial dimana mahasiswa memiliki identitas lain yaitu sebagai orang tua muda di Kota Lhokseumawe.

"Faktor lingkungan termasuk dalam faktor yang mendorong munculnya trend mahasiswa sebagai orang tua muda dan pernikahan dini di Kota Lhokseumawe. saya pikir hal tersebut juga positif, daripada remajaremaj pacaran kelewatan dan tidak menikah, kan nanti bisa terjadi halhal yang tidak diinginkan. Maka menikah dini leboh baik dilakukan. Faktor lingkungan memang sangat mempengaruhi segala bidang dalam kehidupan kita" (Wawancara, 11 Januari 2016).

Pernikahan muda atau pernikahan dini sebenarnaya adalah hal yang sangat baik untuk dilakasanakan oleh manusia, baik dari sisi psikologis maupun sisi adat dan budaya masyarakat kita yang ketimuran. Menikah pada usia muda bukan hanya memberi garansi bagi calon pasangan untuk lebih cepat memiliki keturunan, namun juga sebagai upaya menjaga nama baik keluarga dan adat budaya dalam masyarakat. Kenapa demikian? Karena di tengah kehidupan masyarakat moderen seperti sekarang ini, pergaulan pemuda pemudi yang terkontaminasi budaya Barat 
(westernisasi) sudah sangat susah diatur dan sering bertentangan dengan adat dan budaya ketimuran kita.

\section{Hambatan Mahasiswi sebagai Ibu Muda Dalam Menyelesaikan Studinya di Kota Lhokseumawe}

Hambatan dalam Rumah Tangga

Berdasarkan hasil wawancara dengan informan kunci dalam penelitian ini, maka didapati fakta bahwa ada beberapa hambatan yang mereka temui sebagai orang tua muda di antaranya hambatan dalam rumah tangga yang bisa muncul bervariasi. Setidaknya begitu penuturan beberapa informan saat wawancara. Dari beberapa hambatan yang muncul, beberapa informan mengatakan hambatan yang paling sering muncul adalah ketika anaknya sakit. Bila hambatan itu yang muncul, para orang tua muda harus menerima beberapa resiko seperti berkurangnya waktu tidur karena harus menjaga anaknya yang sedang sakit, merawat rumah juga sedikit terhambat karena anaknya yang sering menangis.

\section{Hambatan dalam Dunia Pendidikan}

Hambatan lain yang ditemui oleh mahasiswa yang menikah muda dan menjadi orang tua bagi anak-anaknya terbentuk dalam wujud hambatan dalam dunia pendidikan. Selain mengurusi keluarga, status mahasiswa yang masih mereka pegang adalah kewajiban lain yang harus mereka laksanakan selain mengurusi rumah tangga. Hal tersebut sering menjadi hambatan lain yang mereka temui dalam menjalani kehidupan sehari-hari.

\section{Penutup}

Fenomena mahasiswi sebagai ibu muda di Kota Lhokseumawe sudah menjadi hal biasa dan tidak dianggap tabu. Ini karena pernikahan usia dini yang melibatkan remaja, khususnya mahasiswi sudah banyak ditemukan.Adapun faktor-faktor yang mendorong munculnya mahasiswi sebagai ibu muda di Kota Lhokseumawe adalah sebagai berikut:Faktor ekonomi keluarga; Faktor kemauan diri sendiri dan orang tua; Faktor Lingkungan; Faktor Lainnya. Faktor ini adalah faktor yang paling ekstrem dan menimbulkan kesan negatif bagi pelaku pernikahan dini. 


\section{Daftar Pustaka}

Buku

Alfian, 1977. Segi-Segi Sosial Budaya Masyarakat Aceh. Depdikbud: Jakarta.

BKKBN, 2012. Buku Petunjuk Berkeluarga. PT. Remaja Rosdakarya: Bandung

Bungin, Burhan. 2008. Penelitian Kuailitatif : Komunikasi, Ekonomi, Kebijkan Publik dan IImu Sosial. Kencana: Jakarta.

Choirunnisa, 2009. Panduan Terpenting Merawat Bayi dan Balita. Moncer Publisher: Yogyakarta.

Edward, D C. 2006. Ketika Anak Sulit Diasuh: Panduan Orang Tua Mengubah Masalah Perilaku Anak. PT. Mizan Pustaka: Bandung.

Fauzil, Adhim, 2002. Indahnya Perkawinan Dini. Gema Insani: Jakarta.

Haryoko, F, 1997. Peran Pengendalian Emosi. Bintang Indonesia: Jakarta.

Kak Seto, 2004. Anak-Anak Balita Bermainlah. Bintang Indonesia : Jakarta.

Koentjaraningrat, 1990. Sejarah Teori Antroplogi. Gramedia: Jakarta.

Moleong, Lexy J, 2000. Metodologi Penelitian Kualitatif. PT. Remaja Rosdakarya: Bandung.

Mubarak, Chayatin, 2009. Ilmu Keperawatan Komunitas Volume 2. Sangung Seto: Jakarta.

Nasruddin, Thoha, 1986. Pedoman Perkawinan Islam. Bulan Bintang: Jakarta.

Roger, M. Keesing, 1999. Antropologi Budaya: Suatu Perspektif Kontemporer. Gramedia: Jakarta.

Ritonga et al, 1996. Fungsi Keluarga Dalam Meningkatkan Kualitas Sumberdaya Manusia Daerah Sumatera Utara. Penyunting: Drs. Arganes Silitonga dan Dra. Misnah Shalihat. Departemen Pendidikan dan Kebudayaan: Medan.

Schohib, 2010. Pola Asuh Anak. Sebuah metodologi. Pustaka Setia: Bandung

Saebani, Bani Ahmad, 2008. Metode Penelitian. Pustaka Setia: Bandung.

Soetjiningsih, 2001. Tumbuh Kembang Anak. EGC: Jakarta.

Soekanto, 1991. Konsep dan Pola Asuh Orang Muda. Gramedia Tua: Jakarta

Sumantri, 1999. Ilmu Sosial Budaya Dasar. Gramedia: Jakarta.

Sunarto, 2007. Bahan Penyuluhan BKR Tentang Materi Ketahanan Keluarga Bagi Calon Pengantin. Jakarta: Badan Kependudukan dan Keluarga Berencana Nasional (BkkbN).

Supanto, dkk, 1990. Pola Pengasuhan Anak Secara Tradisional Daerah Istimewa Yogyakarta. Depdikbud: Yogyakarta.

Supartini, Y, 2004. Buku Ajar Konsep Dasar Keperawatan Anak. EGC: Jakarta.

Supardan, D.2009. Pengantar Ilmu Sosial. Bumi Aksara. 
Wirdhana, Indra, dkk, 2014, Delapan Fungsi Keluarga, BKKBN: Jakarta. William A.Haviland,1988. Sejarah Teori Antropologi. Gramedia: Jakarta.

Skripsi dan Jurnal

Abror, Janan Akmal, 2009. Pola Asuh Orang Tua Karir Dalam Mendidik Anak (Studi Kasus Keluarga Sunaryadi, Kolomplek TNI AU Blok K No 12 Lanud Adisutjipto Yogyakarta). Skripsi Universitas Islam Sunan Kalijaga. Ansori, Acep Aziz, 2015. Dinamika Pernikahan Mahasiswa S-1 di Universitas Muhammadiyah Surakarta. Skripsi Universitas Muhammadiyah Surakarta.

Dwi, Nur Rahmah, 2015. Regulasi Diri dalam Belajar Pada Mahasiswa yang Memiliki Peran Banyak. Jurnal Psikologi.

Juliana, 2015. Pengetahuan Ibu Tentang Merawat Balita Mulieng Manyang, Kecamatan Kuta Makmur Kabupaten Aceh Utara. Skripsi Universitas Malikussaleh.

Kasto, 2002. Mobilitas Penduduk dan Dampaknya Terhadap Pembangunan Daerah Dalam Mobilitas Penduduk Indonesia: Tinjauan Lintas Disiplin. Skripsi Universitas Gajah Mada: Yogyakarta.

Nutfi. (2015). Teori-Teori Dalam Antropologi. Jurnal Antropologi. UNES Press.

Prasetyo, M. 2000. Kesehatan Mental Anak Dalam Keluarga. Skripsi FIB UNNES Semarang.

Thontowi, 2007. Perbuatan yang Melanggar Adat Siri yang Terkait Dengan Kehormatan Perempuan. Skripsi.

Yusmanidar, 2011. Merawat Bayi Di Gampong Blang Crum Keude Dua, Kecamatan Muara Dua Kota Lhokseumawe. Skripsi Universitas Malikussaleh.

Internet

Badan Pusat Statistik (BPS) Kota Lhokseumawe 2016. Lhokseumawe Dalam Angka.

http://www.pesantrenvirtual.com.pernikahan. Diakses 18 Desember 2016. Naviechic.blogspot.co.id/2013/02/penegrtian-orang-tua-html?m=1. Diakses 18 Desember 2016.

Wikipedia, 2003. Sejarah Kota Lhokseumawe. 